DOI 10.22460/infinity.v6i1.231

\title{
A RELATIONSHIP BETWEEN PROBLEM SOLVING ABILITY AND STUDENTS' MATHEMATICAL THINKING
}

\author{
Nita Delima \\ Department of Mathematics Education, Subang University, Indonesia \\ nitadelima85@yahoo.com
}

Received: September 18, 2016; Accepted: November 24, 2016

\begin{abstract}
This research have a purpose to know is there an influence of problem solving abilty to students mathematical thinking, and to know how strong problem solving ability affect students mathematical thinking. This research used descriptive quantitative method, which a population is all of students that taking discrete mathematics courses both in department of Information Systems and department of mathematics education. Based on the results of data analysis showed that there are an influence of problem solving ability to students mathematical thinking either at department of mathematics education or at department of information systems. In this study, it was found that the influence of problem solving ability to students mathematical thinking which take place at mathematics education department is stonger than at information system department. This is because, at mathematics education department, problem-solving activities more often performed in courses than at department of information system. Almost $75 \%$ of existing courses in department of mathematics education involve problem solving at the implementation of courses, meanwhile, in the department of information systems, there are only $10 \%$ of these courses. As a result, mathematics education department students' are better trained in problem solving than information system department students. So, to improve students' mathematical thinking, its would be better, at firstly enhance the problem solving ability.
\end{abstract}

Keywords: students' mathematical thinking, problem solving ability

\begin{abstract}
Abstrak
Penelitian ini bertujuan untuk mengetahui apakah terdapat hubungan yang signifikan antara kemampuan mathematical thinking dengan problem solving mahasiswa program studi sistem informasi dan untuk mengetahui seberapa besar kemampuan problem solving mempengaruhi kemampuan mathematical thinking mahasiswa. Populasi dalam penelitian ini adalah seluruh mahasiswa yang mengontrak mata kuliah matematika diskrit pada program studi Sistem Informasi dan program studi pendidikan matematika. Berdasarkan hasil analisis data diperoleh bahwa terdapat pengaruh yang signifikan antara kemampuan problem solving dan mathematical thinking baik pada mahasiswa prodi sistem informasi maupun pendidikan matematika. Pada penelitian ini, ditemukan fakta bahwa pengaruh kemampuan problem solving terhadap mathematical thinking lebih besar terjadi pada mahasiswa prodi pendidikan matematika. Ini disebabkan, karena kegiatan memecahkan masalah dalam perkuliahan mahasiswa prodi pendidikan matematika lebih sering dilakukan dibandingkan dengan mahasiswa prodi sistem informasi. Hampir $75 \%$ mata kuliah yang ada dalam program studi pendidikan matematika melibatkan problem solving dalam tujuan mata kuliahnya, sementara itu, pada program studi sistem informasi, hanya terdapat $10 \%$ saja mata kuliah tersebut. Akibatnya mahasiswa pendidikan matematika lebih terlatih kemampuan problem solvingnya dibandingkan dengan mahasiswa prodi sistem informasi.
\end{abstract}

Kata Kunci: kemampuan mathematical thinking siswa, kemampuan problem solving 
How to Cite: Delima, N. (2017). A Relationship Between Problem Solving Ability and Students' Mathematical Thinking. Infinity, 6 (1), 21-28.

\section{INTRODUCTION}

Indonesia have two main goals on mathematics education, there is: (1) formal goals, which emphasize the arrangement of reasoning and personality development of the child and (2) material goals, that emphasizes the application of mathematics and problem solving ability in mathematics (Soedjadi, 1999). When learning of mathematics are doing in the classroom, a teacher are often stuck with the second goals of mathematics education, that make some differences perspective of learning mathematics, i.e. viewing mathematics as a process or product. When mathematics is viewed as a product, then in learning activity,a teachers only teach how to doing arithmetic, student is only given some exercises which routine problem, it caused some students lost of interest in doing mathematics itself. It would be different if mathematics is viewed as a process, the teachers will provide a challenge to stimulate the curiosity of students through the given problem, assist them in completing a problem by providing some stimulation, students is directed to think like a mathematician, and of course it is expected can resulting the meaningfull mathematical learning. The mathematics education goals, requires a thinking process of mathematics. It can be a dynamic process that includes the complexity of an idea - the idea of mathematical owned and can expand the understanding of mathematics.

Mason and Johnston-Wilder (Breen \& O'Shea, 2010) says that when a mathematician solved a mathematical problem, their doing some processes and action, like : exemplifying, specializing, completing, deleting, corrected, comparing, sorting, organizing, changing, varying, reversing, altering, generalizing, conjecturing, explaining, justifying, verifying, convincing and refuting, and they called that as mathematical thinking. Stacey (2006) conclude that the ability to think mathematically and to use mathematical thinking to solve a problems is an important goal of schooling. In this point, mathematical thinking ability will support science, technology, economic life and development in an economy. Thus, a student needs to have the ability of mathematical thinking, to enable them mastering anothers materials course.

NCTM (2000) recomended that in teaching and learning mathematics, there are five standards process that must be fulfilled, i.e. problem solving, reasoning and proof, connections, communication, and representation. NCTM mention that standards process problem solving ability includes the ability to: 1) build new knowledge through problem solving ; 2) Solve problems that arise in mathematics and in other contexts; 3) Apply and adapt a variety of appropriate strategies to solve problems; 4) Monitor and reflect on the process of mathematical problem solving. Because problem solving makes it possible to structure knowledge and to bring into connection with the other knowledge, Costa and Kallick (Scusa, 2008), said that the problem solving ability can affects the flexibility of their thinking process.

Based on these analysis, the authors have hypothesis that the problem solving ability can affect the mathematical thinking ability. Therefore, the authors need to do research to prove these hypothesis. 


\section{METHOD}

This study is a quantitative descriptive research that conducted at the Subang University. A population in this study were all of students that taking discrete mathematics courses as many as 32 student of information systems department and 20 students of mathematics education department, then it is taken to be a random sample as many as 20 students from Information Systems department and 13 students from mathematics education department. An instruments in this study is a test of problem solving ability and mathematical thinking. An indicator of problem solving ability test that is compiled based on the standard process from NCTM (2000), which include the ability to: 1) build new knowledge through problem-solving; 2) Solve problems that arise in mathematics and in other contexts; 3) Apply and adapt a variety of appropriate strategies to solve problems; 4) Monitor and reflect on the process of mathematical problem solving. Here is a problem of the tests that is used in this study:

Consider the following map :

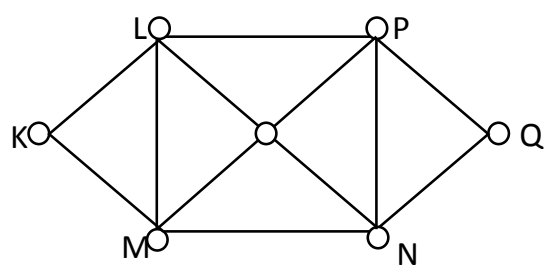

An explorer wants to explore a number of routes between cities on the territory described by the map above. Can you find the routes that only through each road exactly once for him? (Give a reason.) If you can, please state which route can be passed by the explorer.

Meanwhile, the travelers would like to visit a number of cities in the region of the map above. Is there any route so that he can be visiting each city exactly once? If there are exist, please state which route can be passed by the travelers.

The test that is used to measure the mathematical thinking ability have some indicators that is given by Mason, Burton \& Stacey (2010), i.e. (1) specializing : trying special cases, looking at some examples; (2) generalizing: looking for patterns and relationships;(3) conjecturing : predicting relationships and results; (4) convincing: finding and communicating reasons why something is true. Here is a problem of the mathematical thinking tests that is applied in this study:

Somebody invested 10 million on a bank with an annual interest of $10 \%$. Determine the amount of investment after the end of the $1^{\text {st }}$ year until $5^{\text {th }}$ year. If $\mathrm{A}_{\mathrm{n}}$ stated the amount of investment after the end of the $n^{\text {th }}$ year, determine $A_{n}$. Can you find a pattern to determine the amount of the investment at $A_{n}$ ? explain whether the pattern generally accepted? 


\section{RESULTS AND DISCUSSION}

\section{Results}

The objectives of this study is to determine whether there is significant influence problem solving ability of students to mathematical thinking and to determine how strong the problem solving ability can affect students' mathematical thinking. The statistical analysis used in this study is the bivariate correlation analysis. The correlation coefficient is used to see the relationship between these two variables is the Pearson correlation coefficient. As for the calculation of the correlation coefficient performed with SPSS 16.0, while the results can be seen in the Table below:

Table 1. Pearson correlation coefficient

\begin{tabular}{cccccc}
\hline & & \multicolumn{2}{c}{$\begin{array}{c}\text { Information system } \\
\text { Department }\end{array}$} & \multicolumn{2}{c}{$\begin{array}{c}\text { Mathematics Education } \\
\text { Department }\end{array}$} \\
\cline { 3 - 6 } & & $\begin{array}{c}\text { Mathematical } \\
\text { thinking }\end{array}$ & $\begin{array}{c}\text { problem } \\
\text { solving }\end{array}$ & $\begin{array}{c}\text { mathematical } \\
\text { thinking }\end{array}$ & $\begin{array}{c}\text { problem } \\
\text { solving }\end{array}$ \\
\hline $\begin{array}{c}\text { mathematical } \\
\text { thinking }\end{array}$ & $\begin{array}{c}\text { Pearson } \\
\text { Correlation }\end{array}$ & 1 & $.453^{*}$ & 1 & $.736^{* *}$ \\
\hline \multirow{2}{*}{$\begin{array}{c}\text { Sig. (2-tailed) } \\
\text { problem solving }\end{array}$} & $\begin{array}{c}\text { Correlation } \\
\text { Sig. (2-tailed) }\end{array}$ & .045 & .045 & & .004 \\
& & 20 & 20 & 13 & 13 \\
\hline
\end{tabular}

The Table above showed that the Pearson correlation coefficients between problem solving ability and students mathematical thinking from department of information system is at 0.453 with a positive sign, while the Pearson correlation coefficients between problem solving ability and students' mathematical thinking from department of mathematics education is at 0.736 with a positive sign. Based on the criteria on the Table below, an interpretation of the result above, that the strengtness of the relationship between problem solving ability and mathematical thinking from information system student is on moderate level, while the strengtness of the relationship between problem solving ability and students'mathematical thinking from mathematics education students is on strong level.

Table 2. The Criteria of correlation coefficients

\begin{tabular}{cc}
\hline Correlation Coefficients & Interpretation \\
\hline $0.000-0.019$ & Very weak \\
$0.200-0.399$ & Weak \\
$0.400-0.599$ & Moderate \\
\hline
\end{tabular}




\begin{tabular}{cc}
\hline Correlation Coefficients & Interpretation \\
\hline $0.600-0.799$ & Strong \\
$0.800-1.000$ & Very Strong \\
\hline
\end{tabular}

(Sugiyono, 2009: 184)

To determine whether there is a significant influence of the problem solving ability to mathematical thinking, then it is taken a testing of statistical hypothesis as follows :

$$
H_{0}: \rho=0 \text { and } H_{1}: \rho \neq 0
$$

A tests carried out using SPSS 16.0, with the testing criteria as follows:

$H_{0}$ is rejected if Sig. (2-tailed) $<0.05$, whereas $H_{0}$ is accepted if Sig. (2-tailed) $\geq 0.05$

In Table 1 above, it is showed that a Sig. (2-tailed) value of the Pearson correlation coefficient from student in the department of information system is equal to 0.045 , and based on the testing criteria $H_{0}$ is rejected. There are a significant correlation between problem solving ability and mathematical thinking in the department of information system. Meanwhile, the Sig. (2-tailed) value of the Pearson correlation coefficient from department of mathematics education is for 0.004 , and based on the testing criteria $H_{0}$ is rejected. In the other word, we says that there are a significant correlation between problem solving ability and mathematical thinking in department of mathematics education.

Then to see a degree of strengtness of the relationship between the two variables or to find out how strong problem solving ability can contribute to the students' mathematical thinking, the author use the coefficient of determination to describe it. The coefficient of determination can be calculated using the formula:

$$
K D=r^{2} \times 100 \quad(\text { Sugiyono, 2009) }
$$

As for the guidelines to provide interpretation of $\mathrm{KD}$ values, it can be seen in the following Table:

Table 3. Criteria of KD values

\begin{tabular}{cc}
\hline KD values & Interpretation \\
\hline $0 \%-19.9 \%$ & Very weak \\
$20 \%-39.9 \%$ & Weak \\
$40 \%-59.9 \%$ & Moderate \\
$60 \%-79.9 \%$ & Strong \\
$80 \%-100 \%$ & Very Strong \\
\hline
\end{tabular}

(Sugiyono, 2009)

Based on the calculations, KD between problem solving ability and mathematical thinking from department of information system student is $20.5 \%$. This means that the problem solving ability contributed to the mathematical thinking of students as much as $20.5 \%$, while the rest is influenced by other factors that not examined by the authors. According to Table 3, the 
interpretation of $\mathrm{KD}$ values, that is the problem solving ability influence the students' mathematical thinking from department of information system at the low level. Meanwhile, KD between problem solving ability and students' mathematical thinking from department of mathematics education is $54.2 \%$, this means that the problem solving ability contributed to the mathematical thinking of students as much as $54.2 \%$, while the rest is influenced by other factors not examined by the authors. According to Table 3, the interpretation of KD values, that is the problem solving ability influence the students' mathematical thinking from department of mathematics education at the moderate level.

\section{Discussion}

In line with arguement that is proposed by Costa \& Kallick (Scusa, 2008) and Ersoy \& Guner (2015), that the problem solving ability of a person can affects the flexibility of their thinking processes, in this research was found the phenomenon that the problem solving ability of students, both in mathematics education department and information system department, can affect their mathematical thinking. The ability of mathematical thinking itself is a thinking process that is owned by a person who is doing activities of thinking either in mathematics or outside mathematics. Its reinforced by Watson's (2001) opinion that, mathematical thinking is an ordinary ways of thinking and problem-solving which play a specially important part in mathematics. Schorr (2000) also said that, problem solving ability is not just simply recalling algorithms, rules, or procedures, but it is the way the student thinks about problems. So, if student were engaged in problem-solving experiences, it can built their own mathematical thinking.

In this study, it was found that the influence of the problem solving ability to the students' mathematical thinking which is stronger, take place in students' mathematics education department, its because, in this department, a problem solving activities more often performed than information system department. In line with Stacey (2005) that, it would be better if problem solving is now more often treated as a teaching method. Henningsen and Stein (1997); Ishida (1997) ; Weber (2005) also said that in order to develop student capacities in mathemathical thinking ability, it must followed with classroom environments which student are able to engage actively in problem solving task. Nearly $75 \%$ of existing courses in mathematics education department involve a problem solving at the courses, meanwhile, in the information systems department, there are only $10 \%$ of these courses. As a result, students' problem solving ability is better in mathematics education than information system department. Thus, it is clear that the influence of the problem solving ability to the students' mathematical thinking is stronger in students' mathematics education department than students of department of information systems.

\section{CONCLUSION}

Based on the results of data analysis is showed that, there are a significant correlation between problem solving ability and students' mathematical thinking both in the student of information system department and mathematics education department. At the information systems department, problem solving ability contributed to the mathematical thinking of students as much as $20.5 \%$, or in other words, the problem solving ability influence the students' mathematical thinking at the low level. Meanwhile, at the department of mathematics education, problem solving ability contributed to the mathematical thinking of students as much as $54.2 \%$, or in other words the problem solving ability influence the students' mathematical thinking at the moderate level. This is because, at mathematics 
education department, problem solving activities more often performed in courses than at department of information system. Almost $75 \%$ of existing courses in department of mathematics education involve problem solving to the objective of courses, meanwhile, in the department of information systems, its just $10 \%$. As a result, mathematics education department students is better in problem solving ability than information system department students. So, to improve students' mathematical thinking, its would be better, to enhance the problem solving ability at first.

\section{REFERENCES}

Breen, S., \& O'Shea, A. (2010). Mathematical Thinking and Task Design. Irish Mathematical Society Bulletin(66), 39-49.

Ersoy, E., \& Guner, P. (2015). The Place of Problem Solving and Mathematical Thinking in The Mathematical Teaching. The Online Journal of New Horizons in EducationJanuary, 5(1).

Henningsen, M., \& Stein, M. K. (1997). Mathematical Tasks and Student Cognition: Classroom-Based Factors that Support and Iinhibit High-Level Mathematical Thinking and Reasoning. Journal for Research in Mathematics Education, 524-549.

Ishida, J. (1997). The Teaching of General Solution Methods to Pattern Finding Problems Through Focusing On an Evaluation and Improvement Process. School Science and Mathematics, 97(3), 155-162.

Mason, J., Burton, L., \& Stacey, K. (2010). Thinking Mathematically Secon Edition. London: Pearson Education Limited.

NCTM. (2000). Principles and Standards for School Mathematics. Reston, VA: The National Council of Teachers of Mathematics Inc.

Schorr, R. Y. (2000). Impact at the Student Level: a Study of the Effects of a Teacher Development Intervention on Students' Mathematical Thinking. The Journal of Mathematical Behavior, 19(2), 209-231.

Scussa, T. (2008). Five Processes of Mathematical Thinking. Retrieved 2016, from http://digitalcommons.unl.edu/mathmidsummative/38

Soedjadi, R. (1999). Kiat Pendidikan Matematika di Indonesia. Jakarta: Direktorat Pendidikan Tinggi Departemen Pendidikan Nasional.

Stacey, K. (2005). The Place of Problem Solving in Contemporary Mathematics Curriculum Documents. The Journal of Mathematical Behavior, 24(3), 341-350.

Stacey, K. (2006). What is Mathematical Thinking and Why is it Important.Progress Report of the APEC Project: collaborative studies on innovations for teaching and learning mathematics in different cultures (II)_Lesson study focusing on mathematical thinking.

Sugiyono. (2009). Metode Penelitian Bisnis (Pendekatan Kuantitatif, Kualitatif, dan R \& D). Bandung: Alfabeta.

Watson, A. (2001). Instances of Mathematical Thinking Among Low Attaining Students in an Ordinary Secondary Classroom. The Journal of Mathematical Behavior, 20(4), 461475. 
Delima, A Relationship Between Problem Solving Ability and Students' ...

Weber, K. (2005). Problem-Solving, Proving, and Learning: The Relationship Between Problem-Solving Processes and Learning Opportunities in the Activity of Proof Construction. The Journal of Mathematical Behavior, 24(3), 351-360. 